\title{
Selection of duplicates of flax accessions - an important task in the management of collection of genetic resources of Linum usitatissimum L.
}

\author{
GRAŻYNA SILSKA ${ }^{\oplus}$
}

Institute of Natural Fibres and Medicinal Plants National Research Institute

Wojska Polskiego 71B

60-630 Poznań, Poland

Address for correspondence: phone: +48 61 8455838; e-mail: grazyna.silska@iwnirz.pl

\section{Summary}

Introduction: The Institute of Natural Fibres and Medicinal Plants National Research Institute (IWNiRZ) - formerly Institute of Natural Fibres, together with Plant Breeding and Acclimatization Institute (IHAR) in Radzików carry out tasks related to the protection of genetic resources of flax (Linum usitatissimum L.). Genetic resources of flax are stored as seeds in IHAR refrigeration chambers. The research material consisted of passport data of genetic resources of flax.

Objective: The aim of the presenting the identification of duplicates of accessions of flax in documentation of the National Center of Plant Genetic Resources (IHAR). This will facilitate the management of the collection of flax genetic resources. Removal of duplicate accessions from the collection of flax genetic resources will save storage space in long-term chambers, savings in storage costs, savings in working hours.

Methods: The working methods were studying the passport database and the institute's gene bank documentation.

Results: In the cooling chambers of the seed bank at KCRZG at IHAR, unintentional duplicates are stored: 29 flax accessions with the same accessions number and 19 flax accessions with two different accession numbers.

Conclusions: The presentation in the article of two types of duplicates of flax accessions is very helpful in managing the collection of genetic resources of flax. Reducing the number of genotypes in the flax collection will facilitate the faster collection of all valorization data, which will be very helpful for users of the collection of genetic resources of flax. 
Key words: genetic resources, flax, Linum usitatissimum L., duplicates of accessions, collection management

Słowa kluczowe: zasoby genetyczne, len, Linum usitatissimum L., duplikaty obiektów, zarządzanie kolekcja

\section{INTRODUCTION}

Plant germplasm conservation is one of principal items of the Biodiversity Convention [1-3].

Due to geographic-natural and socio-economic conditions, Poland has a large variety of genetic resources, wild species and species, varieties and breeds, occurring both in the wild (in situ) and in ex situ collections [4].

The collection of genetic resources of flax began in the 1920s before the establishment of the Linen-Central Experimental Station in Vilnius in 1930 - the precursor of present Institute of Natural Fibres and Medicinal Plants (IWNiRZ). Gathering the best plants initially and then various European varieties was associated with start of flax cultivation, initially by mass selection and later by cross-breeding method. Initially, all information on the collected flax accessions in the Linum usitatissimum L. genetic resource collection was recorded in paper documentation.

Systematic collection of national genetic resources has been carried out since 1971 [5].

The National Centre for Plant Genetic Resources (KCRZG) of utility plants at Plant Breeding and Acclimatization Institute (IHAR) in Radzików has been working on a documentation system for the needs of users of collected seeds (scientists, growers, business owners, hobbyists and others). Currently, there is a lot of interest concerning stored accessions to obtain information on their biological, agricultural, morphological and technological features [610]. Electronic documentation of valorised features of genetic resources of utility plants is one of the most important tools supporting rational management of collected accessions and their use [6].

The Institute of Natural Fibres (now IWNiRZ) in Poznań has been carrying out tasks related to the protection of genetic resources of flax since 1982 and since 2009 IWNiRZ [11-14]. In 20152020, IWNiRZ provided a research service for IHAR entitled "Collection and preservation in field collections, in vitro and cryopreservation, characteristics, evaluation, documentation and sharing of genetic resources and information in the field of agricultural plants and other useful plants, related wild species and varieties". An important task is to select potential duplicates for verification in terms of their removal from the collection of L. usitatissimum. The removal of unintended duplicates will contribute to a better management of the flax genetic resources collection, which is highly important in public health [15-23].

\section{MATERAL AND METHODS}

The subject of the work was the passport database sent by Martin Pavelek as part of the international (ECP/GR) cooperation. The structure of the International Flax Database Structure, passport part, was obtained after the first meeting of the newly established flax and hemp working group: ECPGR (European Cooperative Programme for Plant Genetic Resources) Working Group on Fibre Crops (Flax and Hemp), in the framework of Sugar, Starch and Fibre Crops Network.

The database of passport collection of flax genetic resources prepared at the IWN was assessed in terms of removing unintended duplicates in the database. Work also consisted of studying the documentation of advanced fibre flax lines grown in the Institute of National Remembrance, submitted for registration research at COBORU. For example, it was noticed that the Polish Gene Bank in Radzików stores the same genotype: No. 165727 - Bryta fiber flax variety (IWN00215) and No. 165504 an advanced breeding line before registration in COBORU, as Bryta, i.e. PET 79. These are duplicates [24]. We strive to reduce the costs of storage in the refrigeration chambers of the collection of crops, therefore, information on duplicates was provided to KCRZG in Radzików.

Tables 1 and 2 provide a list of duplicates stored in the IHAR seed bank of flax accessions with the same accession number (tab. 1) and with different accession numbers (tab. 2). Collecting number is the number of flax samples in long-term storage (KCRZG IHAR).

The survey containing crop-specific genebank standards for orthodox seeds - flax, agreed by the Fibre Crops (Flax and Hemp) Working Group, is available in the website of the National Centre for Plant Genetic Resources, Plant Breading and Acclimatization Institute. 
Table 1.

List of selected duplicates stored in the IHAR seed bank of flax accessions (Linum usitatissimum L.) with the same accession number (collecting number duplicates)

\begin{tabular}{|c|c|c|c|c|c|c|}
\hline \multirow{2}{*}{ No } & \multicolumn{2}{|c|}{$\begin{array}{l}\text { The first seed sample stored flax } \\
\text { accessions }\end{array}$} & \multicolumn{2}{|c|}{$\begin{array}{l}\text { Duplicate seed sample stored flax } \\
\text { accessions }\end{array}$} & \multirow{2}{*}{ Accession number } & \multirow{2}{*}{$\begin{array}{c}\text { Duplicates of flax } \\
\text { accessions (Linum } \\
\text { usitatissimum L.) }\end{array}$} \\
\hline & Accession name & $\begin{array}{l}\text { Collecting } \\
\text { number }\end{array}$ & Accession name & $\begin{array}{l}\text { Collecting } \\
\text { number }\end{array}$ & & \\
\hline 1 & Izolda & 165501 & Izolda & 165575 & IWN00052 & $165501=165575$ \\
\hline 2 & Pet 23 & 165503 & Pet 23 & 165911 & IWN00396 & $165503=165911$ \\
\hline 3 & PET 79 (Bryta) & 165504 & Bryta (PET 79) & 165727 & IWN00215 & $165504=165727$ \\
\hline 4 & Svapo & 165505 & Svapo & 165895 & IWN00382 & $165505=165895$ \\
\hline 5 & LCSD 200 & 165506 & LCSD 200 & 165578 & & $165506=165578$ \\
\hline 6 & Fortuna & 165508 & Fortuna & 165609 & IWN00037 & $165508=165609$ \\
\hline 7 & Minerwa & 165510 & Minerwa & 166058 & & $165510=166058$ \\
\hline 8 & Milenium & 165511 & Milenium & $\begin{array}{l}165910 \\
166056\end{array}$ & IWN00394 & $165511=165910=166056$ \\
\hline 9 & Istru & 165513 & Istru & 165755 & IWN00050 & $165513=165755$ \\
\hline 10 & $\mathrm{I}-7$ & 165540 & $\mathrm{I}-7$ & 165660 & IWN00044 & $165540=165660$ \\
\hline 11 & Pacyfic & 165549 & Pacyfic & 166181 & IWN00088 & $165549=166181$ \\
\hline 12 & Olena Trifolium & 165550 & Olena Trifolium & 165675 & IWN00087 & $165550=165675$ \\
\hline 13 & Iduna & 165568 & Iduna & 165754 & IWN00047 & $165568=165754$ \\
\hline 14 & Ł-1120 & 165581 & Ł-1120 & 165668 & IWN00069 & $165581=165668$ \\
\hline 15 & Marokański & 165586 & Marokański & 165670 & IWN00075 & $165586=165670$ \\
\hline 16 & Natasja & 165590 & Natasja & 165793 & IWN00079 & $165590=165793$ \\
\hline 17 & Istru & 165613 & Istru & 165755 & IWN00050 & $165613=165755$ \\
\hline 18 & Alba & 165708 & Alba & 166205 & IWN00196 & $165708=166205$ \\
\hline 19 & Antares & 165712 & Antares & $\begin{array}{l}166090 \\
166104 \\
\end{array}$ & IWN00200 & $165712=166090=166104$ \\
\hline 20 & ICA 44 & 165753 & ICA 44 & 166117 & IWN00240 & $165753=166117$ \\
\hline 21 & Pet 179 & 165800 & Pet 179 & 165502 & IWN00196 & $165800=165502$ \\
\hline 22 & Waza & 165845 & Waza & 166052 & IWN00328 & $165845=166052$ \\
\hline 23 & Wiko & 166053 & Wiko & 166092 & IWN00605 & $166053=166092$ \\
\hline 24 & Szafir & 166054 & Szafir & 166126 & IWN00636 & $166054=166126$ \\
\hline 25 & Opal & 166055 & Opal & 166125 & IWN00635 & $166055=166125$ \\
\hline 26 & Jitka & 166064 & Jitka & 166147 & IWN00653 & $166064=166147$ \\
\hline 27 & Artemida(SIK 494) & 166066 & Artemida(SIK 494) & 166242 & IWN00778 & $166066=166242$ \\
\hline 28 & Dufferin & 166070 & Dufferin & 166113 & IWN00540 & $166070=166113$ \\
\hline 29 & Laura & 166071 & Laura & 166096 & IWN00536 & $166071=166096$ \\
\hline 30 & CVT-LC-36 & 166209 & CVT-LC-36 & 166278 & --- & $166209=166278$ \\
\hline
\end{tabular}

Table 2.

List of selected duplicates stored in the IHAR seed bank of flax accessions (Linum usitatissimum L.) with different accession number (duplicates collecting number result from duplicates of collection numbers)

\begin{tabular}{|c|c|c|c|c|c|c|c|c|}
\hline \multirow{2}{*}{ No. } & \multicolumn{3}{|c|}{$\begin{array}{l}\text { The first seed sample } \\
\text { stored flax accessions }\end{array}$} & \multicolumn{3}{|c|}{$\begin{array}{l}\text { Duplicate seed sample stored flax } \\
\text { accessions }\end{array}$} & \multirow{2}{*}{$\begin{array}{l}\text { Introduction } \\
\text { number }\end{array}$} & \multirow{2}{*}{$\begin{array}{l}\text { Duplicates of flax accessions } \\
\text { (Linum usitatissimum L.) }\end{array}$} \\
\hline & & $\begin{array}{l}\text { Accession } \\
\text { name }\end{array}$ & $\begin{array}{l}\text { Accession } \\
\text { number }\end{array}$ & & $\begin{array}{l}\text { Accession } \\
\text { name }\end{array}$ & $\begin{array}{l}\text { Accession } \\
\text { number }\end{array}$ & & \\
\hline 1 & IWN00010 & Belinka & 165523 & IWN00212 & Belinka & 165723 & & $\begin{array}{c}\text { IWN00010 }=\text { IWN00212 } \\
165523=165723\end{array}$ \\
\hline 2 & IWN00057 & Kenya & 165571 & IWN00624 & Kenya & 166213 & & $\begin{array}{c}\text { IWN00057 }=\text { IWN00624 } \\
165571=166213\end{array}$ \\
\hline
\end{tabular}


Table 2. (continued)

\begin{tabular}{|c|c|c|c|c|c|c|c|c|}
\hline \multirow{2}{*}{ No. } & \multicolumn{3}{|c|}{$\begin{array}{l}\text { The first seed sample } \\
\text { stored flax accessions }\end{array}$} & \multicolumn{3}{|c|}{$\begin{array}{l}\text { Duplicate seed sample stored flax } \\
\text { accessions }\end{array}$} & \multirow{2}{*}{$\begin{array}{c}\text { Introduction } \\
\text { number }\end{array}$} & \multirow{2}{*}{$\begin{array}{l}\text { Duplicates of flax accessions } \\
\text { (Linum usitatissimum L.) }\end{array}$} \\
\hline & & $\begin{array}{l}\text { Accession } \\
\text { name }\end{array}$ & $\begin{array}{c}\text { Accession } \\
\text { number }\end{array}$ & & $\begin{array}{l}\text { Accession } \\
\text { name }\end{array}$ & $\begin{array}{l}\text { Accession } \\
\text { number }\end{array}$ & & \\
\hline 3 & IWN00068 & Linott & 165580 & IWN00615 & Linott & 166109 & & $\begin{array}{c}\text { IWN00068 }=\text { IWN00615 } \\
165580=166109\end{array}$ \\
\hline 4 & IWN00080 & Noralta & 165591 & IWN00617 & Noralta & 166111 & & $\begin{aligned} \text { IWN00080 } & =\text { IWN00617 } \\
165591 & =166111\end{aligned}$ \\
\hline 5 & IWN00085 & $\begin{array}{l}\text { Ottawa } \\
770 \mathrm{~B}\end{array}$ & 165595 & IWN00660 & $\begin{array}{l}\text { Ottawa } \\
770 \mathrm{~B}\end{array}$ & 166157 & & $\begin{aligned} \text { IWN00085 } & =\text { IWN00660 } \\
165595 & =166157\end{aligned}$ \\
\hline 6 & IWN00088 & Pacyfic & 165549 & IWN00688 & Pacyfic & 166181 & & $\begin{aligned} \text { IWN00088 } & =\text { IWN00688 } \\
165549 & =166181\end{aligned}$ \\
\hline 7 & IWN00172 & Raja & 165684 & IWN00749 & Raja & 166230 & & $\begin{array}{c}\text { IWN00172 }=\text { IWN00749 } \\
165684=166230\end{array}$ \\
\hline 8 & IWN00250 & Kijewskij & 165764 & IWN00705 & Kijewskij & 166197 & & $\begin{array}{c}\text { IWN00250 }=\text { IWN00705 } \\
165764=166197\end{array}$ \\
\hline 9 & IWN00286 & $\begin{array}{c}\text { PEK } \\
382 \text { (Nike) }\end{array}$ & 165803 & IWN00337 & $\begin{array}{c}\text { Nike } \\
\text { (PEK 382) }\end{array}$ & 166051 & $\begin{array}{c}\mathrm{I} 17441= \\
(\mathrm{PEK} 382 ; \\
\text { I17689=Nike }\end{array}$ & $\begin{array}{c}\text { IWN00286= IWN00337 } \\
165803=166051= \\
=\mathrm{I} 17441=\mathrm{I} 17689\end{array}$ \\
\hline 10 & IWN00335 & $\begin{array}{l}\text { Żółtona- } \\
\text { sienny }\end{array}$ & 165852 & IWN00336 & $\begin{array}{c}\text { Żelto- } \\
\text { siemiannyj }\end{array}$ & 165853 & & $\begin{aligned} \text { IWN00335 } & =\text { IWN00336 } \\
165852 & =165853\end{aligned}$ \\
\hline 11 & IWN00340 & Mrija & 165792 & IWN00799 & Mrija & 166252 & & $\begin{aligned} \text { IWN00340 } & =\text { IWN00799165792 } \\
& =166252\end{aligned}$ \\
\hline 12 & IWN00380 & Swietocz & 165893 & $\begin{array}{l}\text { IWN00525; } \\
\text { IWN00609 }\end{array}$ & Swietocz & $\begin{array}{l}166039 \\
166097\end{array}$ & & $\begin{array}{c}\text { IWN00380= IW00525= } \\
\text { IWN00609165893= } \\
166039=166097\end{array}$ \\
\hline 13 & IWN00612 & $\begin{array}{c}\text { Evelin } \\
\text { FRA }\end{array}$ & & IWN00652 & $\begin{array}{c}\text { Evelin } \\
\text { NLD }\end{array}$ & & & IWN00612= IWN00652 \\
\hline 14 & IWN00616 & Hermes & 166110 & IWN00650 & Hermes & 166146 & & $166110=166146$ \\
\hline 15 & IWN00780 & $\begin{array}{c}\text { Selena } \\
(\text { SIK 599) }\end{array}$ & 166201 & & & & $\mathrm{I} 17839$ & $166201=\mathrm{I} 17839$ \\
\hline 16 & IWN00831 & $\begin{array}{l}\text { Agatha } \\
\text { (NLD) }\end{array}$ & 166260 & IWN00836 & $\begin{array}{c}\text { Agatha } \\
\text { (FRA) }\end{array}$ & 166265 & & $\begin{aligned} \text { IWN00831 } & =\text { IWN00836 } \\
166260 & =166265\end{aligned}$ \\
\hline 17 & & Jantarol & 502905 & & & & $\begin{array}{c}12 \\
\mathrm{I} 01004 \\
\end{array}$ & $502905=12 \mathrm{I} 01004$ \\
\hline 18 & & Jan & 505178 & & & & $\begin{array}{c}17 \\
\mathrm{I} 00267 \\
\end{array}$ & $505178=17 \mathrm{I} 00267$ \\
\hline 19 & IWN00779 & Modran & 166203 & & & & $\mathrm{I} 17841$ & $166203=\mathrm{I} 17841$ \\
\hline
\end{tabular}

Ethical approval: The conducted research is not related to either human or animal use.

\section{RESULTS}

In the cooling chambers of the seed bank at KCRZG at IHAR, unintentional duplicates are stored: 29 flax accessions with the same accessions number (tab. 1) and 19 flax accessions with two different accession numbers (tab. 2). For the following flax accessions, three seed samples are stored: Millenium (tab. 1), Antares (tab. 2) and four PEK 382=NIKE (tab. 2).

1. Identification of duplicates in the collection of flax genetic resources will enable the selection of accessions for laboratory and genetic analyses, on the basis of which it will be possible to reduce the number of stored flax accessions by the National Centre for Plant Genetic Resources at IHAR.

2. The selection of duplicates from the collection of flax collected in Poland will contribute to cost savings, space in the storage room and working time of the employees of the long-term storage facility.

\section{DISCUSSION}

The gene bank protects breeding material and many years of achievements of Polish breeders and geneticists [1]. They are a part of the national property [1]. 
By the end of 2020, 829 accessions of flax had been deposited at the KCRZG Gene Bank. These are wild form, landraces, primitive cultivars, breeding lines, varieties of linseed, fibre flax and mixed types of use.

Passport data of the gathered flax accessions were stored in the paper documentation drawn up in accordance with the guidelines of the National Coordinator for Plant Genetic Resources Conservation (IHAR), based on information provided by the letter of October 5, 1987. IHAR recommended the following passport data: 1 . accession number, 2. catalog number (according to the allocation of numbers developed in Radzików), 3. accession name and synonym/variety, former number of breeding line, 4 . genus, 5 . species, 6 . subspecies, 7 . type of accessions (wild -1 , landrace -2 , varieties -3 , breeding lines -4 , mutants -5 ), 8 . country of origin, 9. country of donors, 10 . year the accession was included in the collection, 11. donor catalogue number.

In 2007, the curator of the Linum collection (Grażyna Silska) made a database of passport data collections of flax genetic resources based on the descriptors adopted by the European Cooperative Programme for Crop Genetic Resources Networks - ECP/GR for Plant Genetic Resources for Textile Crops Working Group $[25,26]$. Passport data of the collection of flax accessions was sent to IHAR (Marcin Zaczyński) in 2007.

In general, plant germplasm as well as flax germplasm has only a small practical value, if available genetic resources are not evaluated and characterized according to an acknowledged evaluation system [27]. The identification of unintended duplicates reduces the number of accessions and this enables faster evaluation of the collection of genetic resources. It is a very important task in the management of flax collections of Linum usitatissimum $\mathrm{L}$.

Important information for people managing the collection of flax resources are the names of advanced breeding lines, as this will avoid unnecessary duplicates of stored accessions [28].

The reason for assigning an additional number - accession number - to flax accessions was the lack of computer databases (tab. 1), a mistake in the name - Ewelin, Evelin (tab. 2), two different countries of the donor of the genotype - Agatha from the Netherlands and Agatha from France (tab. 2) or introduction of introduction numbers in place of collecting number in the IHAR seed bank (tab. 2).

\section{CONCLUSIONS}

1. Selecting of duplicates in the collection of genetic resources of flax is a very important task of the protection of genetic resources of cultivated plants.

2. During the preparation of the database of passport accession, collection curators assign a specific accession number to each newly gathered genotype - accession number.

3. The assigned accession numbers of the facilities collected, protected and stored in cold chambers, may not be changed and may not be removed from the already existing passport databases. Genetic resources are not allowed to change an existing accession number.

4. However, knowledge on duplicates in flax collection will allow better management of L. usitatissimum accessions by future curator of the collection and by employees of the National Center for Plant Genetic Resources, both for scrutinizing the storage and supervising the information collected in the Egiset database, which includes passport and valorisation data on plant genetic resources of flax stored at IHAR in Radzików.

5. Two types of duplicate flax accessions are stored in the refrigerated chambers: accessions with the same name under different IHAR numbers or accessions with different names: one sample - advanced breading lines, the other - registered variety.

6. Selected duplicates should be genetically identified for removal from IHAR's long-term storage.

7. Some accessions need to be given the accession number.

Conflict of interest: Authors declare no conflict of interest.

\section{REFERENCES}

1. Kotlińska T, Święcicki WG. Ochrona zasobów genowych roślin uprawnych. Zesz Prob Post Nauk Rol 2004; 497:27-36.

2. Convention on biological diversity. Global strategy for plant conservation. Secretariat of the convention on biological diversity, Montreal, Canada, 2000; http://www.biodiv.org

3. Convention on biological diversity. 2000 Biodiversity Target. Secretariat of the convention 
on biological diversity, Montreal, Canada, 2000; http://www.biodiv.org

4. Raport tematyczny dotyczący dostępu do zasobów genetycznych i związanego z tym podziału korzyści. Ministerstwo Środowiska, Poland; http:/biodiv.gdos.gov.pl

5. Podyma W. Zbiór zasobów genowych roślin użytkowych i ich dzikich przodków oraz stan kolekcji w Polsce. Zesz Prob Post Nauk Rol 1998; 563:31-50.

6. Silska G. The vegetation period of genetic resources of flax (Linum usitatissimum L.). Herba Polonica 2020; 66(3):36-47. doi: http://dx.doi. org/10.2478/hepo-2020-0017

7. Silska G, Bocianowski J. Characterization and evaluation of morphological trials, biological features and seed field of 23 flax accessions ( $\mathrm{Li}$ num usitatissimum L.) of different geographical origins. Herba Pol 2018; 64(4):1-13. doi: http:// dx.doi.org/10.2478/hepo-2018-0019

8. Silska G. Genetic resources of flax (Linum usitatissimum L.) as very rich source of $\alpha$-linolenic acid. Herba Pol 2017; 63(4):26-33. doi: http:// dx.doi.org/10.1515/hepo-2017-0022

9. Silska G. The unique composition of fatty acid of flax, from the Linum usitatissimum L. collection. BJSTR 2019: 13731-13736.

10. Silska G, Walkowiak M. Comparative analysis of fatty acid composition in 84 accessions of flax ( $\mathrm{Li}$ num usitatissimum L.). J Pre-Clin Clin Res 2019; 13(3):118-129. doi. https://doi.org/10.26444/jpc$\mathrm{cr} / 111889$

11. Silska G. Ochrona zasobów genowych dzikich gatunków z rodzaju Linum. Zesz Prob Post Nauk Rol 2004; 497:131-139.

12. Silska G, Praczyk M. Obowiązujące podstawy prawne i metody ochrony zasobów genowych roślin w Polsce - na przykładzie gatunków z rodzaju len [Linum L.]. Herba Pol 2009; 55(3):319327.

13. Silska G, Burczyk H. Genetic resources of the linen (Linum spp.) genus and methods of their storage in Poland. In: Proceedings of the FAO ESCORENA; 2004 Sept 18-19; Sumperk, Czech Republic. 2004:32-38.
14. Silska G, Praczyk M. Deskryptory charakterystyki i waloryzacji Międzynarodowej Bazy Danych Lnu. Biul IHAR 2013; 268:161-171.

15. Budwig J. Flax oil as a true aid against arthritis, heart infarction and cancer. Apple Publishing Co Ltd. 1994.

16. Oomah DB. Flaxseed as a functional food source. J Sci Food Agr 2001; 81(9):889-894.

17. Jelińska M. Kwasy tłuszczowe - czynniki modyfikujące procesy nowotworowe. Biul Wydz Farm AMW 2005; 1:1-9.

18. Matławska I, Bylka W. Naturalne niezbędne kwasy tłuszczowe w profilaktyce chorób cywilizacyjnych. Herba Pol 2007; 53(2):39.

19. Łoźna K, Kita A, Styczyńska M, Biernat J. Skład kwasów tłuszczowych olejów zalecanych profilaktyce chorób cywilizacyjnych. Probl Hig Epidemiol 2012; 93(4):871-75.

20. Rudzińska M, Wąsowicz E. Niezbędne nienasycone kwasy tłuszczowe. In: Czapski J, Górecka D, eds. Żywność prozdrowotna - składniki i technologia. 2nd ed. Poznań. Wydawnictwo Uniwersytetu Przyrodniczego w Poznaniu, 2015:219-235.

21. Janiak MA, Silska G, Penkacik K, Sulewska K, Karamać M, Amarowicz R. Flax seed as a source of antioxidants. In: Proceedings of the $34^{\text {nd }}$ Scientific Conference: Oilseed Crops 2018; Poznań, Poland. 2018:115-116.

22. Silska G. Nasiona lnu zwyczajnego (Linum usitatissimum L.) w prewencji chorób nowotworowych. In: Bazylak G, Kaznowski A, Różański H. Rośliny zielarskie, kosmetyki naturalne i żywność funkcjonalna. Medycyna naturalna w onkologii. 1st ed. Krosno. Państwowa Wyższa Szkoła Zawodowa im. Stanisława Pigonia w Krośnie, 2017:272-304.

23. Silska G. Nasiona lnu zwyczajnego (Linum usitatissimum L.) jako żywność funkcjonalna w prewencji chorób mózgu. In: Materiały konferencyjne V Konferencji pt. „Rośliny zielarskie, kosmetyki naturalne i żywność funkcjonalna”; 2018 May 10-11; Krosno, Poland. 2018:114-115.

24. Silska G. Opis dwunastu dawnych odmian lnu wyhodowanych w Polsce, Zagadnienia Doradztwa Rolniczego 2017; (3):111-122. 
25. Pavelek M. Descriptors for evaluation of flax. In: Workshop summary of the second meeting of the flax; 1994 Nov 8-9; Brno, Czech Republic. 1994.

26. Pavelek M, Faberova I. Klasifikator (Linum usitatissimum L.). 1st ed. Sumperk. Agritec, Research, Breeding \& Services, LTD, 2000.
27. Nozkova J. Descriptors for flax (Linum usitatissimum L.). 1st ed. Nitra. Slovak University of Agriculture in Nitra, 2011.

28. Rutkowska - Krause I, Kozłowski R, Silska G. Flax and hemp gene bank of the Institute of Natural $\mathrm{Fi}$ bres. In: Flax Genetic Resources in Europe; 2001 Dec 7-8; Praque, Czech Republic. 2001:49-54. 